\title{
Liability, war and peace
}

\section{Andrew Alexandra}

\section{Taking pacifism seriously}

War is one of the most important institutions of the modern international system. It comprises the organisations dedicated to preparing for and fighting wars - the extensive standing armies, armaments manufacturers, intelligence agencies and the like possessed by all modern states- as well as the technology produced and utilized by those organisations, and the rules and norms that govern their activities, specifying the reasons why wars may be threatened or entered into, and how they may be fought, and what should follow from their termination.

Pacifism and Just War Theory (JWT) are two major theoretical approaches to that institution. JWT, while accepting the in-principle legitimacy of the institution of war, places significant normative constraints on both entry into and fighting of wars. Pacifism, on the other hand, in its modern manifestation is a social movement committed to the rejection of war as a means to resolve international disputes, and to its replacement with non-violent alternatives. While some members of the pacifist movement have been absolutists, holding that support for, or participation in, a war could never be justified, others - contingent pacifists - have thought that, prior to the construction of viable institutional alternatives to war, it is at least possible that sometimes support for, or participation in, a war could be justified ${ }^{1}$.

JW theorists and contingent pacifists may agree in particular judgments; that a specific war is justified, for example. And it is possible that those who accept the more restrictive versions of JWT may think that facts such as the destructive power of modern weaponry means that wars no longer satisfy the conditions for justification. Nevertheless, JWT and (contingent) pacifism should not be assimilated to each other. JWT theorists accept war in principle, and are involved in constructing and refining its normative framework, while pacifists reject the institution of war and are committed to the construction of institutional alternatives to $\mathrm{it}^{2}$. (In what follows I refer to the two kinds of institutions which are advocated by JWT theorists and pacifists as military and pacifist institutions.)

\footnotetext{
${ }^{1}$ For historical discussions of pacifism as a socio-political movement in the UK and US see eg Martin Ceadel The Origins of War Prevention Oxford: Clarendon Press, 1996 and Semi-Detached Idealists: The British Peace Movement and International Relations, 1854-1945 Oxford: Oxford University Press, 2000; Charles Chatfield The American Peace Movement: Ideals and Activism New York: Twayne, 1992, Peter Brock Pacifism in the United States from the Colonial Era to the First World War Princeton: Princeton University Press, 1968 and Freedom from Violence: Sectarian Nonresistance from the Middle Ages to the Great War Toronto: University of Toronto Press, 1991.

2 The term 'pacifist' has come to have a variety of senses, including opposition to any form of physical violence. However, the word pacifism came into the English language to refer to the view that it is possible to resolve international disputes without resort to violence, an idea which has been a central animating force in the broad pacifist movement. For further discussion see Andrew Alexandra 'Political Pacifism' Social Theory and Practice (USA) Vol. 29, no. 4 (October 2003) pp.589-606 esp. pp. 590-95., Jenny Teichmann Pacifism and the Just War: A Study in Applied Philosophy Oxford: Basil Blackwell, 1986, esp. Ch. 1. Much of the discussion of pacifism in the philosophical literature assumes that pacifism is an inherently absolutist doctrine, an assumption which could only be made by those innocent of the history of the pacifist movement.
} 
There are, moreover, more fundamental agreements between pacifism and JWT. First, both see war as bad, and peace as good. Secondly, though they disagree about its structure, pacifists and JW theorists agree on the need for an institution the primary purpose of which is to prevent states from attempting to solve international disputes through the use of coercive force. Such an institution has three related functions. The first is the deterrence of aggression. If aggression nevertheless occurs, the second function is to resist it, and the third is to re-establish the status quo ante as quickly and fully as possible. Discussion of military defence, including of its ethics, has tended to focus on the second of these - repelling aggression - but that function is logically subordinate to the others, since its value is derived from its role in assisting the realization of the other functions. The capacity to resist is fundamental to effectiveness of deterrence, and to the restoration of the status quo ${ }^{3}$. Finally, since Michael Walzer's seminal reinterpretation of JWT In Just and Unjust Wars ${ }^{4}$, most JW theorists, like pacifists, see their claims as grounded in, and arising out of, ordinary moral thought, rather than by appeal to, say, the rights of sovereigns. Writing from within the JW tradition, Jeff McMahan, for example, says that justifications for killing people in war are of the same forms as the justifications for the killing of persons in other contexts. The difference between war and other forms of conflict is a difference only of degree and thus the moral principles that govern killing in lesser forms of conflict govern killing in war as well. A state of war makes no difference other than to make the application of the relevant principles more complicated and difficult because of the number of people involved, the complexities of their relations with one another, and the virtual impossibility of having knowledge of all that is relevant to the justification of an act of killing. ${ }^{5}$ (And, of course, this claim is generalized to other normative claims about war made by JW theorists.)

The comparative merits of military and pacifist institutions can be assessed against the background of these agreements. That assessment, it is fair to say, has barely begun, at least in the realm of academic philosophy. The reason is obvious: it has been taken for granted that pacifism is a utopian doctrine, with no realistic prospect of non-violent means being effective against organized violence in the international sphere. Effectiveness is a necessary condition for a proposed social policy, so pacifism can simply be rejected without further discussion. These claims are, it seems, so self-evident that no empirical evidence is necessary to support them, despite the existence of a number of historical examples of effective political campaigns, including resistance to invasion and defiance of invaders, which have used nonviolent tactics. Such tactics were of primary importance, for example, in the overthrow of the Iranian Shah in the late 1970s, the removal of the Marcos regime in the Philippines in the 1980s, and the eventually successful struggle of the East Timorese to remove the Indonesian invaders in the 1990s. ${ }^{6}$

\footnotetext{
${ }^{3}$ Given this agreement, both pacifists and JW theorists may also agree about the desirability of institutional arrangements such as arms inspection authorities, forums for the adjudication of international disputes, and so on, which make the resort to force less likely or costly.

${ }^{4}$ Michael Walzer Just and Unjust Wars: A Moral Argument with Historical Illustrations New York; Basic Books 1977

${ }^{5}$ Jeff McMahan Killing in War Oxford: Oxford University Press, 2009, p. 156

${ }^{6}$ Gene Sharp is the most notable recent theorist of non-violent resistance. See eg Gene Sharp CivilianBased Defence: A Post-Military Weapons System Princeton: Princeton University Press, 1990 and From Dictatorship to Democracy London: Serpent's Tail 2012. Strategy and tactics drawn from Sharp's work in particular are widely held to have played an important role in recent popular struggles in the Middle East. Historical accounts of non-violent resistance are found in eg Peter Ackerman and
} 
In their recent important book Why Civil Resistance Works: The Strategic Logic of Nonviolent Conflict ${ }^{7}$ Erica Chenoweth and Maria J. Stephan actually considered relevant historical evidence. They analysed data for three kinds of large scale political campaigns - anti-regime, anti-occupation and self-determination - dating back to the start of the twentieth century, categorised each campaign as either violent or nonviolent, and found that far from it being the case that non-violence was inherently ineffective, non-violent campaigns were significantly more effective than violent campaigns, in gaining both short- and long-term goals,.

\section{Institutional structures}

No doubt Chenoweth and Stephan's analysis is contestable ${ }^{8}$, but it surely shows that the relative standing of pacifist and military institutions, and in particular the arrangements for national defence which lie at the heart of those institutions, merits serious consideration. Since of course no nation has constructed anything like a thorough-going pacifist defence system, the outline of a system to figure in such consideration must, to some extent, be prescriptive. The one sketched here, however, is not fanciful; it is grounded in a substantial body of non-violent thought and practice developed over the last century ${ }^{9}$. Theorists have identified a very wide range of nonviolent tactics (198 on Gene Sharp's count) which can be used in political campaigns, grouped under the headings of 'protest and persuasion' (such as demonstrations and renunciation of honours), 'non-cooperation' (such as civil disobedience and strikes) and 'interventions' (such as sit-ins, creation of alternative institutions, and counterfeiting).

Chenoweth and Stephan's examination of the historical record shows that effective resistance (violent or non-violent) is highly correlated with popular support and participation, which in the case of non-violent resistance is facilitated by the variety of non-violent tactics available so, for example, even the physically frail or timid can find ways of participating. It also shows that in the case of non-violent resistance, success is correlated with a decentralised organisational structure, so that resistance is not vulnerable in the face of the removal of a single, or small number of, sources of authority, and allows resistance campaigns to draw on the strengths of different groups, who are best placed to tailor their actions to local conditions and to innovate as they see $\mathrm{fit}^{10}$. Successful resistance campaigns have tended to make use of existing

Christopher Kruegler, Strategic Non-Violent Conflict: The Dynamics of People Power in the Twentieth Century London: Praeger, 1994; Peter Ackerman and Jack DuVall A Force More Powerful New York: St. Martin's, 2000; Erica Chenoweth and Maria J. Stephan Why Civil Resistance Works: The Strategic Logic of Nonviolent Conflict New York: Columbia University Press, 2011, finds that non-violent methods are significantly more effective.

${ }^{7}$ Chenoweth and Stephan Why Civil Resistance Works: The Strategic Logic of Nonviolent Conflict op. cit.

${ }^{8}$ Commentators have noted difficulties in accurately classifying particular campaigns, for example. It is not easy to decide whether has a campaign should be counted as successful when its aims are not fully achieved, or are moderated in the course of the campaign. Similarly, there are often difficulties in deciding whether a campaign is violent or nonviolent, when both strategies coexist and combine, or when there are shifts over time from one to the other.

10 See Chenoweth and Stephan Why Civil Resistance Works: The Strategic Logic of Nonviolent Conflict op.cit. 
social institutions, such as churches, as sites for organisation, recruitment and communication. Moreover, non-violent resisters aim not (simply) to prevail through making the preferred strategy of their opponents too costly to maintain, but also through engagement with those who are attempting to coerce them, allowing for the possibility of reasoned dialogue, compromise and agreement on mutually advantageous outcomes, as well as making it likely that there will be shifts in the loyalty and commitments of members of the group of would-be coercers.

An effective pacifist system of defence, then, as well as relying on non-violent tactics, will be broad-based, decentralised and integrated with other social institutions. In each of these ways it differs from the national armies which are at the heart of the institution of war. Modern armies are highly specialised organisations, both in their mission - the provision of high levels of lethal force - and their equipment, and are staffed by experts in the use of that equipment to carry out the organisational mission.

Fundamental to the laws and ethics of war, as that ethics has come to be popularly understood, is a categorical distinction between members of the armed forces and others - civilians - who are not supposed to participate in war-fighting, and which is embodied in the organisational separation of the military from civilian life. Armies operate with a centralised decision-making procedure, and a hierarchical chain of command. There seem to be two reasons for that structure. Firstly, conventional military activity involves large numbers of people carrying out complex, interlocking activities, the success of which relies on a high degree of coordination - coordination which can only be brought about through centralised authority. Secondly, the tools of violence can generally be used for purposes other than for national defence. Those who patronise armies need assurance that they will only be used in the ways they want them to be, and having a hierarchical authority structure which is ultimately answerable to them is a means to that goal (though, as history shows, not a very reliable one.) Armies, then, are creatures of the state. This is not true of pacifist defence systems, which in virtue of their decentralised nature, are not, and cannot be, controlled by the state, even if sponsored and supported by it.

Military and pacifist institutions thus fall on different sides of the line dividing what I'll call formal and informal institutions and organisations. H.L.A. Hart's distinction between primary and secondary rules ${ }^{11}$ helps explain the difference. A formal organization possesses both primary rules - rules specifying what behaviors are required, permitted or forbidden for members - and secondary rules - rules specifying the powers that members have to introduce, change, and adjudicate on the primary rules. It possesses structures of (coercive) authority which lays down and enforces rules regulating membership, the status of members (in respect, for example, of their authority relations), and the standards of behavior which apply to them. An informal organisation, on the other hand, possesses primary but not secondary rules. It lacks structures of authority, even though members share, and recognise each other as sharing, internalized norms regulating their behaviour and the way they treat each other.

${ }^{11}$ H.L.A. Hart, The Concept of Law (Oxford: Oxford University

Press, 1961), pp. 77-96. 
In terms of this distinction, then, armies, and the states of which they are supposed to be agents, are formal organisations, while pacifist defence systems of the kind outlined above, are informal organisations.

\section{Normative implications}

These differences between armies and pacifist defence systems ground significant differences in the normative demands they make on participants. The centralised, hierarchical nature of armies, on the one hand, and the decentralised, non-hierarchical nature of pacifist defence systems on the other, are fundamental to this difference.

Wesley Hohfeld's taxonomy of normative concepts, in particular the twinned notions of liability and immunity, help illuminate the nature of these demands ${ }^{12}$. For Hohfeld, someone bearing liability can be identified with their being subject to another agent's (normative) power - the ability of that agent to change the subject's normative standing - in particular their power to impose a disadvantage. More colloquially, of course, it refers to that disadvantage once imposed. Someone's possessing immunity, on the other hand, means that others do not have such power to change their normative situation.

In what might be called positive common morality - the morality we actually accept in our dealings with each other - each person is liable to every other. So if a person engages in certain forms of bad behaviour others are permitted, or even obliged, to treat them in ways which are normally forbidden, or at least inappropriate. Though there is a prima facie demand that we accept others testimony as honest, for example, that demand lapses in the case of a notorious liar. (Positive common morality is itself an example of an informal institution of the kind outlined above, albeit one which is reinforced and supported in a range of ways by law and public policy.) A pacifist institution of defence, dedicated to non-violent resistance, aims to maintain and reassert the validity of existing moral norms against the illegitimate use of coercive force to usurp political power.

The formal structure of the state and its military arm, on the other hand, allows for the creation and enforcement of normative structures which differ significantly from those which would hold in their absence. In terms of the Hohfeldian concepts outlined above, a state has a range of legal powers over their own citizens and those of enemy states which are activated in wartime. Soldiers on both sides lose the immunity against intentional harm which everyone otherwise enjoys, and at the same time gain the right - indeed, the duty, if so ordered - to attack members of the armed forces of enemy states, and to risk their lives ${ }^{13}$. While non-combatants retain their immunity

12 Wesley Hohfeld, 'Some Fundamental Legal Conceptions as Applied in Judicial Reasoning', 23 Yale Law Journal 16 (1913) http://www.hiit.fi/files/ns/Herkko/SOME\%20FUNDAMENTAL\%20LEGAL\%20CONCEPTIONS\% 20AS\%20APPLIED\%20IN\%20JUDICIAL\%20REASONING.pdf

${ }^{13}$ So the British Ministry of Defence states in its 2000 publication The Military Covenant that 'All British soldiers share the legal right and duty to fight and if necessary, kill, according to their orders and an unlimited liability to give their lives in so doing. This is the unique nature of soldiering'. Quoted in Patrick Mileham 'Unlimited Liability and the Military Covenant' Journal of Military Ethics 9 (1):23-40 (2010) 
from intentional attack, they lose the immunity which they otherwise have against foreseen grievous bodily harm and destruction of property if that occurs in the course of military activity. 'Trading With the Enemy' Acts remove citizens' rights to engage in commerce with individuals or organisations domiciled in enemy states and permit the (otherwise illegal) quarantining or confiscation of the property owned by citizens of enemy states. Emergency and martial laws enacted in wartime provide states with very extensive control over their own citizens, including abrogation of their normal legal rights against detention, seizure of property and so on.

The extraordinary legal powers which states possess, and their implications for the changes in the status of people in wartime, obviously require justification. In Just and Unjust Wars $^{14}$, Michael Walzer aimed to show that they are justified, because such changes are morally justified ${ }^{15}$. Since, it is claimed, soldiers on both sides are equally morally liable to attack, it is right that they should be legally liable to attack; since all civilians retain their moral status of immunity to attack, they should be legally immune as well, and so on ${ }^{16}$.

On the face of it, the claim that changes in the legal status of people in wartime track the changes in their moral status is surprising, for those changes do not seem to reflect the connections that hold between responsibility and liability in common morality. Firstly, while responsibility for a wrong is normally a necessary condition for being liable to have a harm imposed on one, many of those who become liable to harm in war have done nothing wrong. Many civilians, for example, bear no responsibility for the war, but nevertheless have no claim against military forces which have harmed them or destroyed their property if those actions occur in the course of legal military activity. Secondly, the extent of liability is normally sensitive to the weightiness of the wrong committed. But this does not hold in war - a politically influential civilian may bear much greater responsibility for a state's decision to launch and continue an unjust war than many of that state's soldiers, but it is the soldiers who are liable to intentional targeting, not the civilian.

If, with JWT, it is thought that wars can be justified, but that at most one of the belligerents can be just, the disconnection of responsibility and liability in war appears to apply both to the equal liability of soldiers to attack, and the equal immunity of civilians from attack. The soldiers on the unjust side are complicit in the commission of a very grave wrong, as are those civilians on the unjust side who willingly provide material support to the war, while soldiers and their civilian supporters on the just side are simply trying to prevent that wrong, and doing so in a permissible way. It is standardly held that those who are trying to prevent others from committing a wrong do not thereby lose their liability to being harmed (by the wrongdoers), while wrongdoers do lose their liability to coercive action, where such action is necessary to prevent the wrong and is proportionate to it. Walzer, in effect, argued that in fact the standard connection between responsibility and liability does hold for soldiers and civilians in their relations to each other in wartime, even when

\footnotetext{
${ }^{14}$ Michael Walzer Just and Unjust Wars: A Moral Argument with Historical Illustrations New York; Basic Books 1977

15 Even if those changes are morally justified, it does not follow, of course, that states rightfully possess the power to impose them.

16 The blanket prohibitions against 'trading with the enemy' would appear particularly difficult to justify in this way - but JWT theorists don't seem to have turned their attention to this issue.
} 
one side is fighting a just war and the other isn't. Walzer appealed to the ethics of self-defense, which allows a person to kill someone who they reasonably believe is trying to kill them, when such killing is the only way in which they can defend themselves. A soldier at war presents a lethal threat to his opponents by virtue of his being armed, and so forfeits his right not to be attacked by them. A civilian does not present a lethal threat, and so has not has forfeited her right not to be attacked.

Recent 'revisionist' JW theorists - perhaps most notably Jeff McMahan - have accepted with Walzer that the morality of war is continuous with common morality but denied that that morality supports either Walzer's doctrine of 'the moral equality' of combatants which makes them equally liable to attack, or of the moral equality of non-combatants which renders them morally immune from attack. ${ }^{17}$. Helen Frowe provides a neat summary of what she calls the 'reductive individualist' account of the ethics of war. According to Frowe

This account is reductivist because it holds that the rules which govern killing in war are reducible to the rules governing interpersonal killing in ordinary life. Indeed, for a reductivist, war is part of ordinary life, insofar as it is governed by the same moral principles that govern all our activities. ${ }^{18}$

Consistent with this approach, McMahan provides an account of liability to attack which applies in both peace and war. For McMahan, a person is morally liable to (potentially lethal) attack, provided the attack is used to avert an objectively unjust threat, where: (1) The threat, if realized, will wrongfully harm another; (2) the person is responsible for creating the threat; (3) killing the person is necessary to avert the threat, and (4) killing the person is a proportionate response to the threat. Soldiers of a state waging an unjust war satisfy these conditions, so are liable for attack; soldiers of a state justly (according to JWT) resisting such an attack who fight according to the laws of war don't, so aren't. Similar reasoning shows that some non-combatants complicit in the unjust attack also may be liable for attack. On McMahan's view, then, what he calls the 'deep morality' of war is not reflected in the laws of war. Nevertheless, he holds that the laws of war are justified on pragmatic grounds, as conventions which, if generally conformed to, limit the destructiveness of wars overall.

Whether the tension between the laws and ethics of war inherent in the revisionist view can be negotiated seems to me to be moot. But in any case, it is a mistake to think that the norms of liability which apply to our dealings with each other in peacetime also apply in war.

\section{Liability in a 'Community of Risk'}

\footnotetext{
17 See for example C. A. J. Coady, "The Status of Combatants" in D. Rodin and H Shue eds. Just and Unjust Warriors: The Moral and Legal Status of Soldiers Oxford: Oxford University Press, (2008) pp. 153 -75; Cecile Fabre "Guns, Food, and Liability to Attack in War," Ethics 120 (2010): 36-63; Helen Frowe Defensive Killing: An Essay on War and Self-Defence Oxford: Oxford University Press, 2014; Jeff McMahan "Innocence, Self-Defense and Killing in War" Journal of Political Philosophy 2 (1994):193-221, “The Ethics of Killing in War” Ethics 114 (2004):693-732, Killing in War Oxford: Oxford University Press (2009): Lionel McPherson, “Innocence and Responsibility in War" Canadian Journal of Philosophy (2004) 34 :485-506, David Rodin War and Self-Defense, Oxford: Clarendon Press, (2002).

${ }^{18}$ Helen Frowe Defensive Killing: An Essay on War and Self-Defence op. cit, p. 13.
} 
Despite their differences, Walzer and the revisionists share two fundamental presumptions which underpin their approach to the moral assessment of the norms of war: that the norms apply to individuals, rather than to collectives such as nations, states, institutions or organisations; and that they apply in virtue of particular actions which those individuals have (or have not) undertaken.

On this individualist view, questions of liability arise in relation to the distribution of costs which are the result of the action of one person who acts in a way which produces harm to another. If we think that the person who is harmed should not have to bear the costs of such action, we establish rules which make the agent liable (either strictly, or if they have breached a standard of care). If we think that agents should be allowed to act in ways which nevertheless may cause harm to others, we make agents immune from liability, and oblige those who may be harmed to bear either the harm or the cost of measures to prevent or mitigate it. (And of course one of the functions of systems of rights, moral and legal, is to provide guidance about these things.)

On the individualist approach, causal responsibility is a necessary condition for liability. The principle of causal responsibility is, of course, deeply embedded in ordinary thinking about moral responsibility and, consequently, liability for moral sanction (such as blame or shunning). It is also reflected at least up to a point, in the law, especially tort law ${ }^{19}$.

However, it is a mistake to think that it is always a necessary condition for liability, especially in collective undertakings. The distinction which Gregory Keating draws within the broad category of actions between 'the world of acts' and 'the world of activities' helps understand why. Keating uses the term 'acts' to refer to actions taken by unrelated agents, typically individuals or small enterprises, acting independently of each other, while 'activities' refers to actions undertaken as part of, and in furtherance of, large scale, interdependent, systems. My chopping down a tree in my back yard for fuel for my fire is an act; the transmission of gas from the gas plant through a complex series of pipes to my gas heater is an activity ${ }^{20}$.

The individualist approach to liability is appropriate for acts. There are two kinds of reasons to be taken into account in determining rational liability arrangements for acts, those of fairness and efficiency. Prima facie, it is fair that people should bear the costs, as well as receive the benefits, of their own actions, and conversely, it is unfair if those who have not agreed to bear the costs of others' actions, and do not benefit from them, should be forced to bear their costs. In such cases, it is reasonable to make agents liable (for compensation or punishment) if they act in ways which predictably imposes costs on others. Efficiency recommends that policies regarding liability for certain kinds of action should be determined according to cost-benefit calculations. If it is generally more profitable for the agent to bear the costs, as well as

\footnotetext{
${ }^{19}$ Only up to a point, because 'enterprise liability' requires enterprises as a whole to spread the costs of the kinds of risky activities which are seen as characteristic of the enterprise across the enterprise as whole, rather than requiring the person(s) who was the proximate cause of a harm to bear the cost. The 'enterprise' may be a firm, industry or a whole society. (New Zealand's wellknown no-faulty insurance scheme for traffic accidents is an example of a society-wide enterprise liability scheme.)

20 Gregory Keating 'Strict Liability and the Mitigation of Moral Luck' Journal of Ethics and Social Philosophy Vol. 2, No. 1, August 2006
} 
gain the benefits, of their actions, the policy will require that they be liable for imposing those costs on others. If it is more profitable for the costs to remain with the subject of harm, agents should be immune.

Considerations of fairness and efficiency may conflict or coincide ${ }^{21}$. But since agents are typically in a better position to foresee the likely costs of their actions and make choices to avoid action which will impose costs on others or to mitigate those costs, in our ordinary interactions with each other, it is often both fairer and more efficient to make agents liable for imposing unwanted costs on others.

The same considerations apply in the case of activities, but they have different implications for the allocation of liability. I'll focus on activities which involve what Keating calls 'communities of risk', where those who receive the benefits of an activity also assume the risks of bearing harms consequent on it. Activities are instrumental in the provision of many of the goods we rely on in modern, complex societies. In the course of an activity it is predictable that those actions which generate benefits will also generate harms, though it is not predictable when the harms will occur, or who will be the particular agents or subjects of those harms. Hence, while the benefits of an activity are widely distributed, the harms are concentrated.

Typically, the actions of people involved in realizing the purpose of an activity will produce greater social good than the private good they receive, and if the risks inherent in their actions produce harm, the cost of the harm may also be much greater than the private good they receive from their part in the activity. Keating gives the example of a fuel tanker driver. A fuel tanker produces serious risks for those on its route. If fuel tanker drivers were obliged to bear the full costs of harms produced by their actions, no rational person would engage in this activity, with a consequent loss to all those who benefit from it. Those at risk of harm may be in a similar position. So the catastrophic cost of being involved in an accident with a fuel tanker may be greater than the (substantial) benefits of having access to fuel, and it would be irrational for people to expose themselves to such risks if they could prevent it (by refusing permission for tankers to use roads that pass their dwellings, for example). An efficient liability arrangement - one that maximizes the likelihood of people engaging in mutually beneficial activities - will distribute the costs of (potential) harms generated in the course of activity among members of the community, rather than concentrating them, as on the individualist approach, either on the agent responsible for the harm, or the subject of the harm. Considerations of fairness of the kind appealed to, for example, in Hart's 'principle of fair play' ${ }^{22}$ also recommends distribution of costs of an activity among a community of risk: those who benefit from a collective activity should bear a fair share of the burdens of the activity. This kind of cost spreading, particularly in large and dispersed communities, generally requires the exercise of coercive authority - in other words the existence of what I have called a formal organization above.

In the light of this discussion, let me now return to the question of the justification of the various changes in the (legal) normative status of citizens consequent on their

21 Talbot Page 'Responsibility, Liability and Incentive Compatibility' Ethics Vol. 97, No. 1, (Oct. 1986) pp. 240-262

${ }^{22}$ Hart, H. L. A. (1955). “Are There Any Natural Rights?” Philosophical Review, 64: 175-91. 
states going to war with each other. Firstly, consider the liability of soldiers: on the one hand more limited than in peace-time, since they are immune from prosecution for killing or helping to kill as part of unjustified aggression; on the other, much greater, since they do not have the rights to avoid potentially fatal situations in the course of their mission.

There are at least three reasons in favour of limiting soldiers' liability for participation in unjustified aggression. The first two concern the allocation of costs. Since everyone benefits from the existence of peace, and everyone is exposed to the risks consequent on the activities dedicated to preserving it, that institution is a 'community of risk', where those who receive the benefits of an activity also assume the risks of bearing harms consequent on it. Ideally, then, its costs would be evenly distributed among all those who participate in it (ie everybody). However, given the organizational structure of armies, soldiers obviously bear much greater burdens than civilians. As many commentators have pointed out, soldiers are often not well placed to assess the justness of the war in which they engage, or to refuse to serve in one which they do judge to be unjust. In many cases, it is purely a matter of luck that a soldier finds themselves engaged in a just, rather than unjust, war. If soldiers were to be liable for participating in an unjust war, the costs of their participation in the institution of war would be higher even than they currently are. Moreover, the risks of having to pay such costs exist even if a soldier never actually does engage in an unjust war, given that we know that states of all political ideologies are prone to wage unjust wars. Making soldiers liable for participation in an unjust war would have the effect either of stopping rationally self-interested people from enlisting in armies, subverting the desirable capacity of those armies to play their part in the institution of war, or impose the risks of costs on soldiers disproportionate to the benefits they receive, and to the risks of costs imposed on others. Hence making soldiers liable would either be inefficient, (the first reason) or unfair (the second).

The third reason also applies to the justification of the immunity of civilians from intentional targeting in war, or subsequent punishment, even when they are willfully complicit in the waging of an unjust war. As claimed above, the ultimate purpose of the institution of war is to maintain and restore peace - the fighting of wars is a means to this. But peace here is not simply the absence of war, it is the condition of settled social life, what Hobbes calls 'commodious living'. Maintaining immunity of noncombatants during wartime, like maintaining immunity of essential infrastructure, helps ensure that the conditions for the restoration of social life remain in place. Mechanisms for allocating liability post-war would have to be highly intrusive and their effects extremely disruptive. Current arrangements have the effect of minimizing the ongoing disruption to peace-time life - they conduce to the realization of the aims of the institution of war.

\section{Conclusion}

If the argument sketched in the previous section is persuasive it shows that there are moral, not merely pragmatic reasons to accept the norms of war accepted by traditional JWT and enshrined in law, especially non-combatant immunity and the equal liability of combatants. It also follows that even if those norms are grounded in ordinary rational and moral principles, they differ considerably from the norms regarding responsibility which hold in peace-time. 
Even if justified in terms of the rationale of the institution of war, there are good reasons to be concerned about these norms. At the very least, they protect those who promote and profit from war from bearing the full consequences of their actions, creating 'moral hazard' where disincentives for irresponsible behavior are lacking. Moreover, the liability arrangements currently in place are deeply at variance with those which apply in common morality, as the revisionist JW theorists have recognised. It is clearly difficult to quarantine norms generated in major social institutions from influencing - and perhaps subverting - attitudes more generally. For example, given the prima facie prohibition on the use of violence, we normally demand an account when someone does use it. The permission which soldiers have to engage in violence during war-time means that they do not have to provide such an account. It clearly does not follow that either they or others should not nevertheless engage in critical reflection on, and debate about, the justness of the war they are engaged in or the means by which it is being pursued. Nevertheless, it now seems to be broadly accepted that public condemnation of the activities of the armed forces is somehow an act of disloyalty to 'our boys'.

In contrast, since the norms embodied in pacifist defence systems really are part of common morality, such systems generate neither of the risks of moral hazard or subversion of ordinary morality which inhere in military systems. 


\section{University Library}

\section{- M M N E R VA A gateway to Melbourne's research publications}

Minerva Access is the Institutional Repository of The University of Melbourne

Author/s:

Alexandra, A

Title:

Liability, War, and Peace

Date:

2015-01-27

Citation:

Alexandra, A. (2015). Liability, War, and Peace. Philosophical Forum, 46 (1), pp.41-53. https://doi.org/10.1111/phil.12054.

Persistent Link:

http://hdl.handle.net/11343/292547 